\title{
A Numerical Study on Local Depressions on the Lee Side of the Hidaka Mountain Range in Hokkaido*
}

\author{
By Kikuro Tomine \\ Institute of Meteorology, The Defense Academy, Yokosuka, 239, Japan \\ (Manuscript received 17 October 1983, in revised form 10 February 1984)
}

\begin{abstract}
It has been well-known that extraordinary deep local depressions are frequently observed at Urakawa on the west side of the Hidaka mountain range in Hokkaido (Arakawa, 1960), when the easterly prevails near the surface. Any easterly near the surface has a critical level, because the westerly prevails over Japan usually. The present numerical investigations show that the local depressions are responsible for a shear flow including a critical level. The results are as follows:

1) In the case of a uniform flow, the surface pressure differences between the both feet' of the mountain range increase with the wind speed when it is small, and are maintained with small constant values when it is large.

2) The local depressions on the lee side are detected on the mid-slope, not on the foot, of the mountain range and the upper atmosphere is affected significantly by the mountain range.

3) In the case of a shear flow including a critical level, the surface pressure differences increase with increasing wind speed.

4) The local depressions appear on the foot of the mountain range and the atmosphere above the critical level is not affected seriously by the mountain range.
\end{abstract}

\section{Introduction}

It has been well-known that extraordinary deep local depressions are observed occasionally at Urakawa on the west side of the Hidaka mountain range (e. g., Arakawa, 1960). It is usually considered that such large mountain waves occur in the following three cases.

The first is the case of a hydraulic jump. The shallow water model is applicable to the atmosphere with a strong inversion layer. The flow below the inversion layer cannot be steady when Froud number is very large, and hydraulic jumps take place on the lee side of the mountain range (Arakawa, 1960; Arakawa and Okano, 1976; Houghton and Kasahara, 1968).

The second is the case of small internal Froud number. When the atmosphere is stable

* Dedicated to Professor G. Onishi on the occasion of his retirement. and the wind is very weak, the flow cannot be steady and mountain waves of a large amplitude are observed (Long 1952, 1955; Scorer and Klieforth, 1958; Furukawa, 1973, 1977).

The last is the case of occurrence of strong reflection of mountain waves from the upper layers. When there are inversion layers or layers with large vertical gradient of Scorer number, they reflect significantly the mountain waves on the lee side (Klemp and Lilly, 1975, 1978).

We do not take the first and the second explanations following after Klemp and Lilly (1975). They said "A basic element of hydraulic jump theory is the nonexistence of continuous finite-amplitude solutions for a certain range of Froud number $(F)$ when the ambient fluid consists of one or more constant density layers in steady motion. Even the linear solution becomes singular at $F=1$. It 


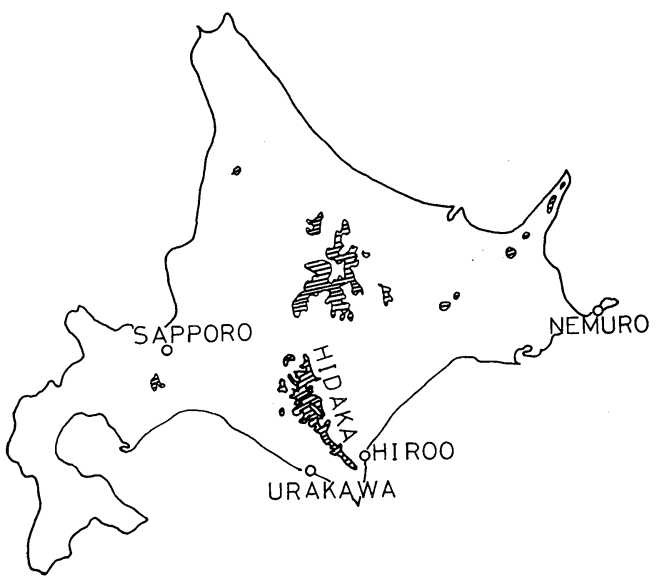

Fig. 1 Positions of the observational stations. Areas higher than $1 \mathrm{~km}$ are shaded.

is important to recognize, however, that the linear singularity no longer exists if the fluid above the density discontinuity is continuously stratified and is subject to a radiation boundary condition".

The last explanation is mainly adopted to the atmosphere where upper winds are stronger than lower ones. For the extraordinary deep local depressions mainly observed at Urakawa, however, the easterly prevails near the surface. Urakawa is located on the west side of the Hidaka mountain range as shown in Fig. 1. When the easterly and the westerly prevail near the surface and in the upper atmosphere, respectively, the normal components of the upper and the lower winds to the mountain range have different signs. We investigate numerically the characteristics of such a shear flow including a critical level over a mountain range.

The governing equations and the numerical model adopted here are given in Section 2. In Section 3, the characteristics of the local depressions are discussed for both uniform flow with an inversion layer and a shear flow including a critical level with uniform gradient of potential temperature over a mountain. It will be suggested there that the shear flow is important to build the deep local depressions. The characteristics of the local depressions for those two kinds of flow are investigated in Section 4.

\section{Governing equations for numerical model}

The two-dimensional disturbances are considered in a plane constructed by the vertical direction $(z)$ and the normal direction to a mountain range $(x)$. They obey the hydrostatic and the Boussinesq approximations. The governing equations are following:

$$
\begin{aligned}
& \frac{\partial u}{\partial t}+u \frac{\partial u}{\partial x}+w \frac{\partial u}{\partial z}=-C_{p} \Theta \frac{\partial \pi}{\partial x} K \nabla^{2} u+D \\
& \frac{\partial \theta}{\partial t}+u \frac{\partial \theta}{\partial x}+w \frac{\partial \theta}{\partial z}=K \nabla^{2} \theta \\
& \frac{\partial u}{\partial x}+\frac{\partial w}{\partial z}=0 \\
& C_{p} \Theta \frac{\partial \pi}{\partial z}=\frac{g}{\Theta} \theta
\end{aligned}
$$

where $u$ and $w$ are the $x$ - and $z$-components of velocity, $\theta$ and $\pi$ the deviation of potential temperature and the Exner function, respectively, from those of the adiabatic atmosphere with a constant potential temperature $\Theta$ $\left(300^{\circ} \mathrm{K}\right) . \quad C_{p}$ is the specific heat for dry air at constant pressure, $g$ the acceleration of gravity, $D$ the Rayleigh damping term for the disturbances, $K$ the eddy diffusion coefficient for momentum and heat assumed to be 100 $\mathrm{m}^{2} / \mathrm{sec}$. We do not adopt any turbulence adjustment procedure (e.g., Klemp and Lilly, 1978) for the region with Richardson number less than $1 / 4$.

(a) Geometry of the computation domain with a mountain profile

The computation domain is a rectangular one divided by grids of $201 \times 301$. The grid size is $1.5 \mathrm{~km}$ horizontally and $50 \mathrm{~m}$ vertically, which corresponds to a $300 \mathrm{~km} \times 15 \mathrm{~km}$ rectangular domain. The mountain range is set at the center of the domain, the height and the width of which are $1 \mathrm{~km}$ and $30 \mathrm{~km}$, respectively, comparable to those of the Hidaka mountain range. The time increment is $5 \mathrm{sec}$ and Euler backward method is adopted. The integrations are carried out till the initial transient disturbances created near the mountain reach the lateral boundary on the lee side to avoid reflections of them from the boundaries. 
(b) Boundary conditions

Slipping and adiabatic boundary conditions are assumed at the surface.

$$
\frac{\partial u}{\partial n}=\frac{\partial \theta}{\partial n}=0
$$

where $\frac{\partial}{\partial n}$ represents a normal component of a gradient to the configuration of the ground. For $w$ the following form is assumed,

$$
w=u \frac{d f}{d x},
$$

along the surface, where $f(x)$ represents the profile of the mountain.

Rayleigh damping term $D$ in eq. (1) is applied for the upper layer (Tanaka, 1975), which absorbs disturbances like a sponge. Here $D$ is represented as follows :

$$
\begin{aligned}
& D=-K_{1} \Delta u=-K_{1}\left(u-U_{i}\right), \\
& K_{1}=K_{2} \frac{e-\exp \left(\frac{h+s-z}{s}\right)}{e-1},
\end{aligned}
$$

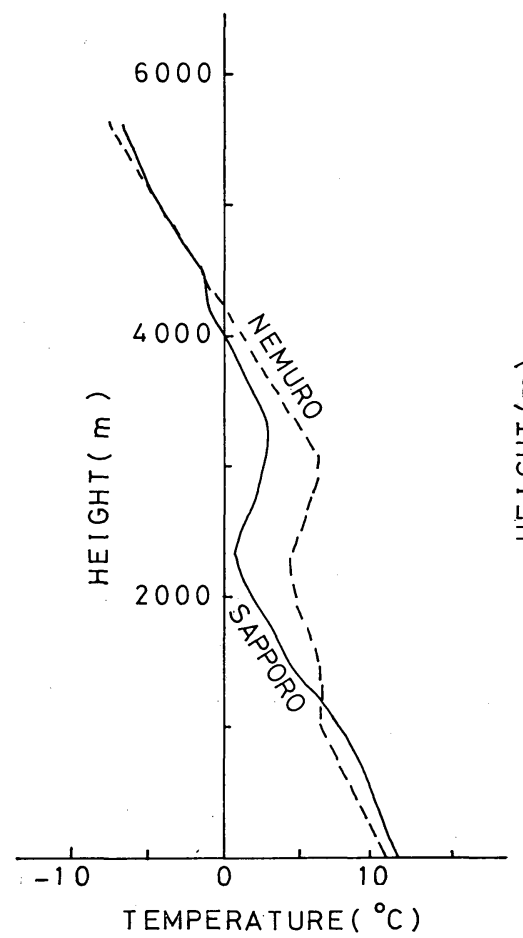

(a) where

$$
\begin{aligned}
& K_{2}=10^{-3} \mathrm{sec}^{-1}, \\
& s=5 \mathrm{~km},
\end{aligned}
$$

and

$$
h=10 \mathrm{~km},
$$

where $s$ denotes the thickness of the sponge layer $(5 \mathrm{~km})$ and $\Delta u$ is a deviation from the initial flow $\left(U_{i}\right)$. Slipping and adiabatic boundary conditions are assumed for the top of the sponge layer, in which a constant pressure is also assumed. For lateral boundary conditions, $u$ is constant and $\partial \theta / \partial x$ is zero (Furukawa, 1973).

(c) Initial conditions

At the initial step of the time integration (say, $t=0$ ), the mountain range is abruptly introduced into the field of horizontal current.

\section{Characteristics of shear flow including a critical level}

Characteristics of the depressions of two flow types over the mountain range are in-

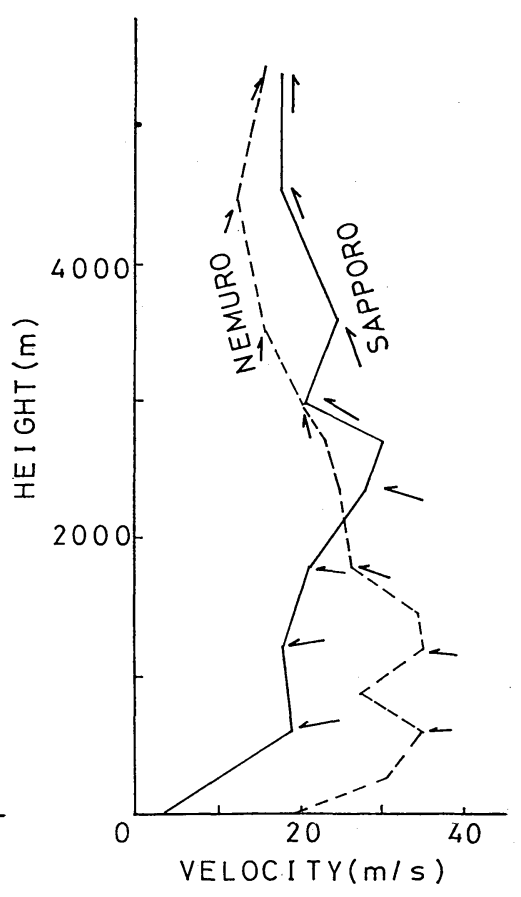

(b)

Fig. 2 (a) Temperature profiles and (b) profiles of wind speeds and directions at 0600 GMT on 27 September 1958 at Nemuro and Sapporo. 
vestigated. One is the case of a uniform flow with an inversion layer and the other is the case of a shear flow including a critical level with a uniform vertical gradient of potential temperature. For an example of the local deep depressions, we adopt the data at 0600 GMT on 27 September, 1958 (Arakawa, 1960). At that time the surface pressure difference between Urakawa and Hiroo, the both feet of the Hidaka mountain range, is about $15 \mathrm{mb}$, and the vertical profiles of temperatures and winds at that time at Nemuro and Sapporo are shown in Fig. 2. A thick inversion layer is found between $2000 \mathrm{~m}$ and $3000 \mathrm{~m}$ levels in Fig. 2(a) while the lapse rates of the other layers are about $5^{\circ} \mathrm{C} \mathrm{km}^{-1}$. Fig. 2 (b) shows winds veering vertically. The winds at the same pressure levels at Nemuro and Sapporo are averaged. The averaged winds are considered to represent the basic flow over the Hidaka mountain range. The vertical profile of the normal components of them to the

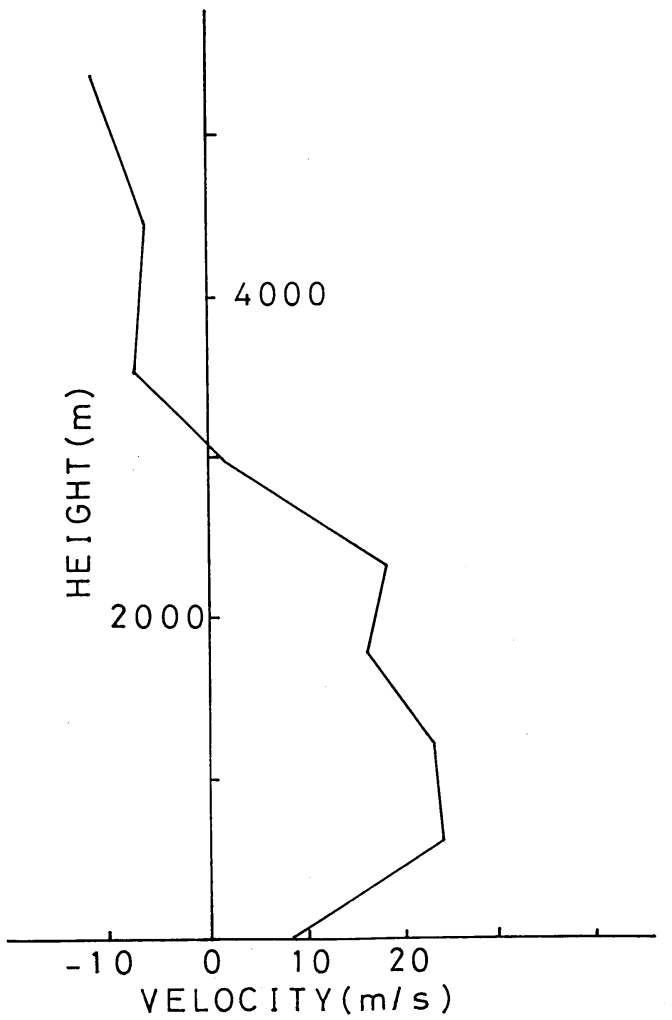

Fig. 3 Vertical distributions of the normal components of averaged winds at Nemuro and Sapporo on the same time as in Fig. 2. mountain range is shown in Fig. 3. The normal components of the winds are about $20 \mathrm{~m} / \mathrm{sec}$ in the lower atmosphere and sign of the components changes at about $3 \mathrm{~km}$.

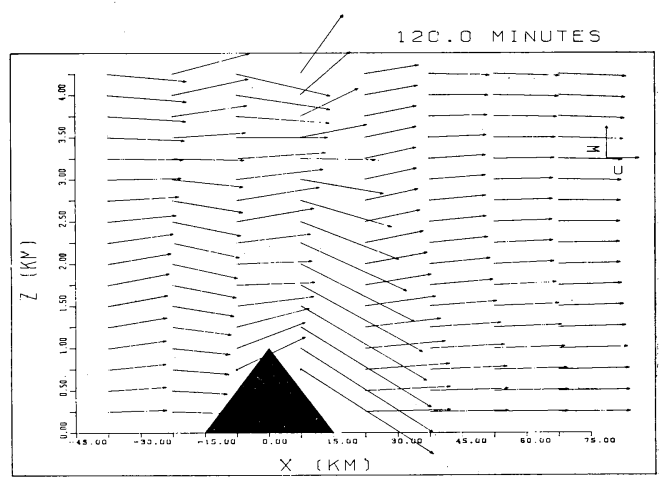

(a)

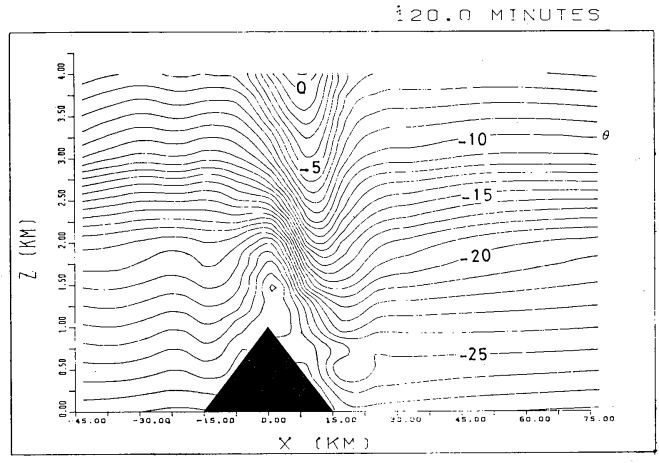

(b)

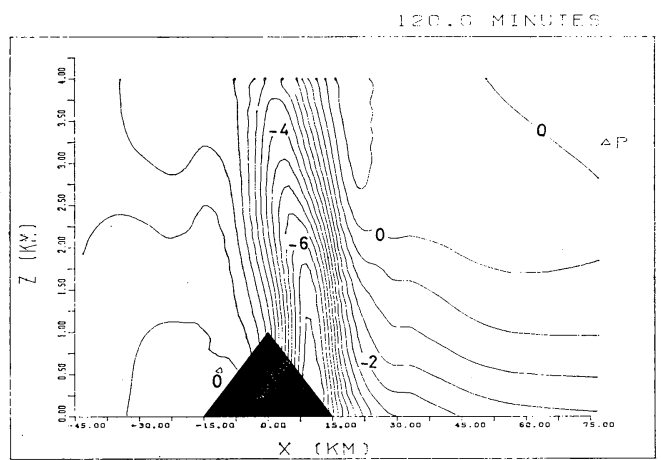

(c)

Fig. 4 Numerical results of distributions of (a) winds, (b) potential temperature and (c) deviations of pressure from the initial state, for the uniform flow after two hours from the initial moment. Arrows in the right upper corner in (a) represent $10 \mathrm{~m} \mathrm{sec}^{-1}$ and $1 \mathrm{~m} \mathrm{sec}^{-1}$ for $u$ and $w$, respectively. The mountain is shaded. 
Based on the synoptic situations of temperature and wind mentioned above, a uniform flow of $20 \mathrm{~m} \mathrm{sec}^{-1}$ with the lapse rate of $5^{\circ} \mathrm{C}$ $\mathrm{km}^{-1}$ except a weak inversion layer between $2 \mathrm{~km}$ and $3 \mathrm{~km}$ is firstly assumed to investigate the influences of the inversion layer to the flow over the mountain range. The flow after two hours from the initial instant is shown in Fig. 4. The distributions of velocity, potential temperature and pressure deviations from the initial state are shown in Figs. 4(a), (b) and (c), respectively. The atmospheric flow from the surface to the top of the domain for present calculation is influenced largely by the mountain range as shown in Fig. 4. The local depression on the lee side is found on the mid-slope of the mountain and the surface pressure difference between the both feet of the mountain (points at $x= \pm 15 \mathrm{~km}$ ) is only about $3 \mathrm{mb}$. These are the characteristics of a uniform flow over the mountain range, and the characteristics obtained are not so sensitive for the change of the height and the intensity of the inversion layer.

Next, a shear flow shown in Fig. 3 is treated keeping the constant lapse rate to be $5^{\circ} \mathrm{C} \mathrm{km}^{-1}$. The situations after two hours from the initial state are shown in Fig. 5. The critical level on the windward side is higher than that in the initial state by about $500 \mathrm{~m}$ as shown in Fig. 5(a). Influences of the mountain range become weak rapidly above the critical level (about $3 \mathrm{~km}$ height) and a large trough is built just below the original critical level above the leeward foot of the mountain range as shown in Fig. 5 . The large trough seems to be a kind of a Kelvin-Helmholtz billow (Tanaka, 1975). The local depression is observed on the leeward foot of the mountain and the surface pressure difference between the both feet of the mountain is about $9 \mathrm{mb}$. The intensification of the local depression is mainly due to the trough formed by the nonlinear critical level effects, probably. In the both cases we suspect the occurrence of stagnations from the distributions of potential temperature on the windward side of the mountain range. In the present numerical model, the stagnation does not vanish for large Froud number.

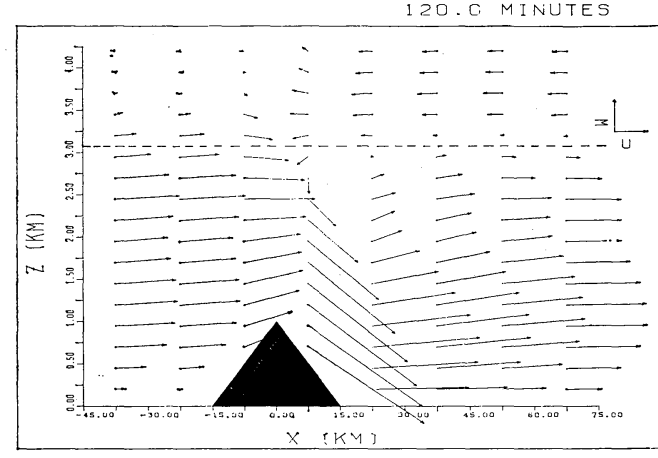

(a)

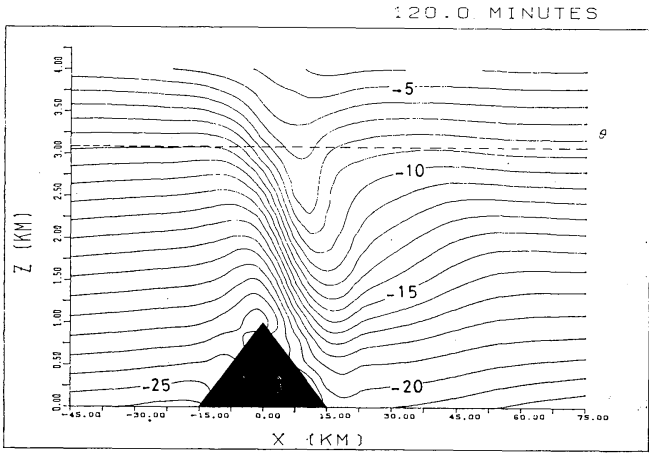

(b)

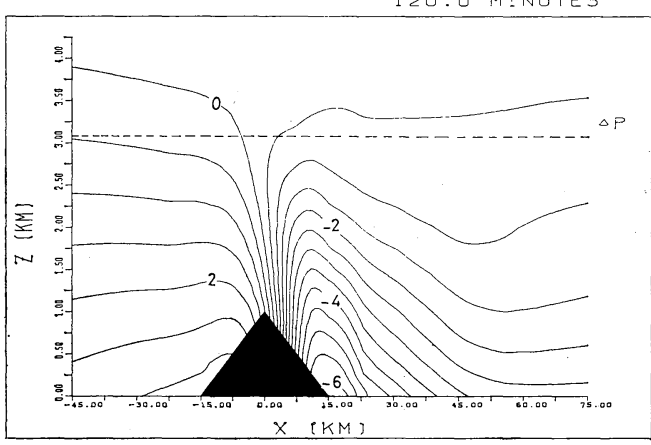

(c)

Fig. 5 Same as Fig. 4, but for the shear flow. Broken lines represent the initial positions of the critical levels.

Time changes of surface pressure differences between both feet of the mountain $(\Delta P)$ are shown in Fig. 6 in the two cases. The pressure differences of the uniform flow with the inversion layer drop after an initial large turbulence and converge into a relatively small value. However, $\triangle P$ of the shear flow including a critical level maintains a large value 


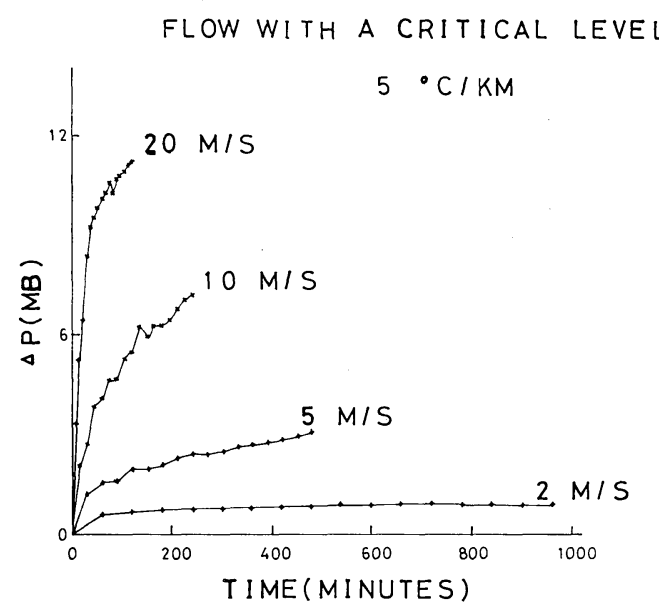

Fig. 6 Time evolutions of $\Delta P$ for uniform flow with a stable layer and shear flow (real wind) with uniform gradient of potential temperature.

for a long time. The results obtained above show that the shear flow represented in Fig. 3 is important to generate a large differences of surface pressures between the both feet of the mountain range.

\section{Characteristics of surface pressure differences between the both feet of the mountain range}

The characteristics of $\Delta P$ are investigated numerically in both shear and uniform flows. As a typical example, a hyperbolic tangent shear flow is assumed (e.g., Tanaka, 1975). The distribution of velocity at the initial state is represented as follows:

$$
U_{i}(z)=-U \tanh \left(z-z_{c}\right) / z_{0},
$$

where $z_{c}$ is the critical level for a steady wave, $U$ the representative velocity of the shear flow, and $z_{0}$ is assumed to be $1 \mathrm{~km}$.

Time evolutions of $\Delta P$ for several wind velocities of $U$ are shown in Fig. 7. Time integrations are continued till the initial transient disturbances created near the mountain range reach the lateral boundary on the lee side. Figs. 7 (a) and (b) represent time evolutions of $\Delta P$ for uniform flows and shear flows, respectively. Initial vertical gradient of potential temperature is assumed to be $5^{\circ} \mathrm{C} \mathrm{km}^{-1}$ in both cases and the height of the critical level $z_{c}$ is adopted $3 \mathrm{~km}$. In Fig. $7(\mathrm{a})$,

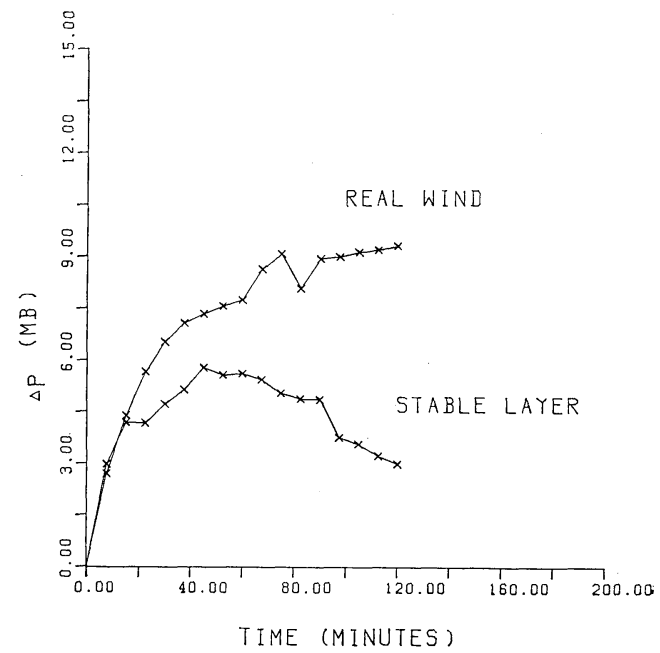

(a)

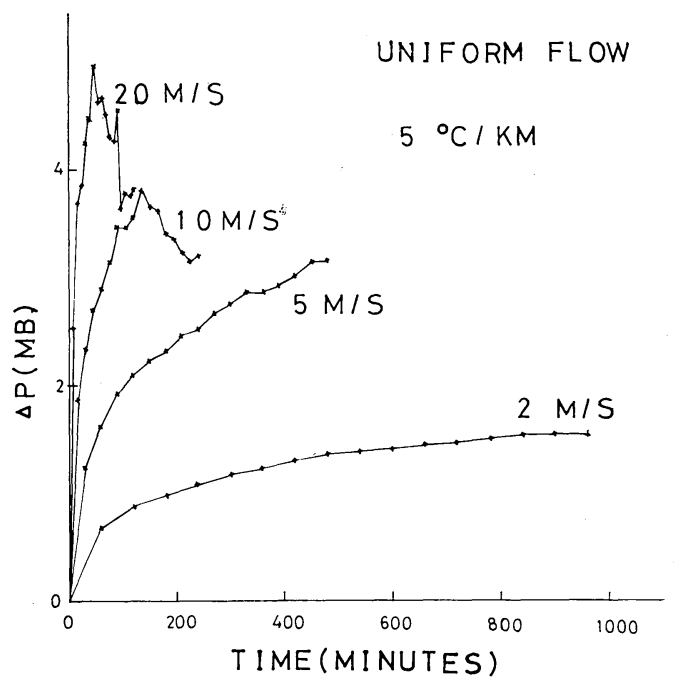

(b)

Fig. 7 Time evolutions of $\Delta P$ for (a) uniform flows and (b) shear flows.

$\Delta P^{\prime}$ 's for several wind velocities of $U$ converge to constant values at the end of the integral. Large $\Delta P^{\prime}$ 's are found for strong winds in the early stages, but they decrease rapidly to smaller values as time elapses. In Fig. 7 (b), $\Delta P$ 's is still increasing slowly at the final stages. Several $\Delta P^{\prime}$ 's at the stages for various wind velocities of $U$ are shown in Fig. 8 . In the case of uniform flows, $\Delta P$ 's increase with wind velocities of $U$ for small $U$ region while they maintain a nearly constant value for large $U$ region. In the case of shear flows, $\Delta P$ 's increase with $U$ monotonicaliy. 


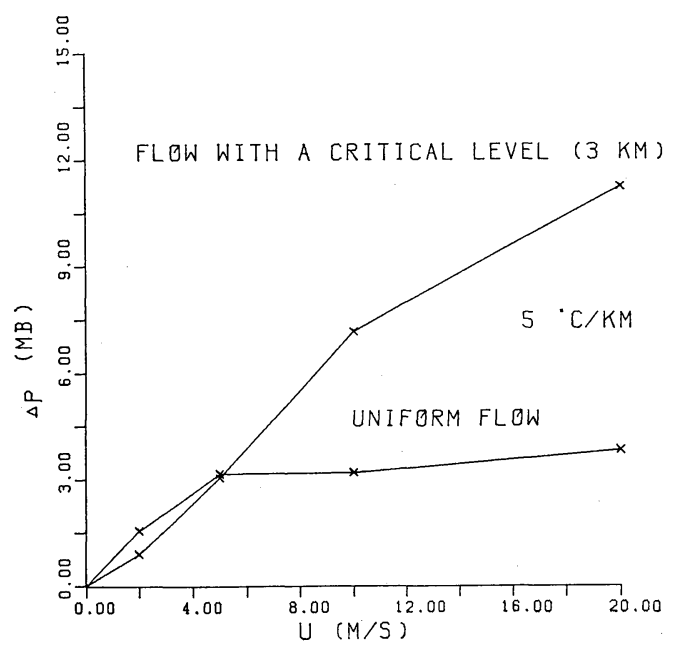

Fig. 8 Variation of $\Delta P$ vs. $U$, for uniform flows and shear flows.

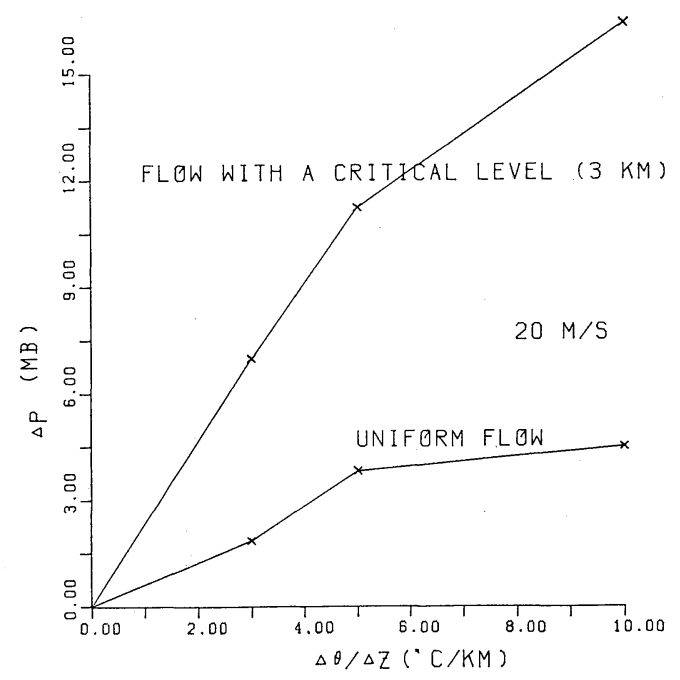

Fig. 9 Variation of $\Delta P$ vs. $\Delta \theta / \Delta Z$ for uniform flows and shear flows.

Several examples of $\Delta P$ for various vertical gradient of potential temperature from the numerical model are shown in Fig. 9, where wind speed is $20 \mathrm{~m} \mathrm{sec}^{-1}$ and $\Delta P^{\prime}$ 's are after 120 minutes times integrations. $\Delta P^{\prime}$ 's increase almost proportionally with vertical gradient of potential temperature in the both cases of shear and uniform flows, though the increasing rates are very different each other. The rate in the shear flows is about five times larger than that in the uniform flows.

Lastly, the influences of the height of the

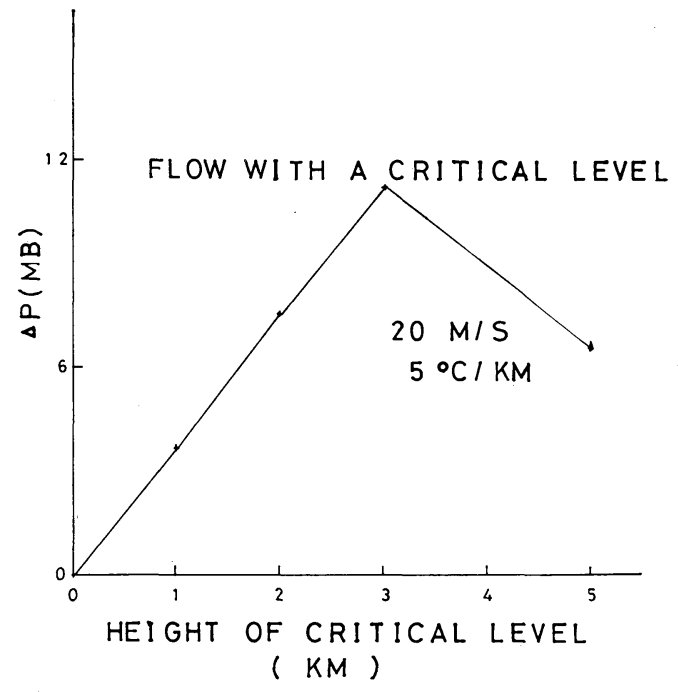

Fig. 10 Variation of $\Delta P$ vs. the height of the critical levels $\left(z_{c} \mathrm{~km}\right)$. The velocity and the vertical gradient of potential temperature are $20 \mathrm{~m} / \mathrm{sec}$ and $5^{\circ} \mathrm{C} \mathrm{km}^{-2}$, respectively.

critical level on $\Delta P$ are investigated numerically. Fig. 10 shows the results for the shear flows of $20 \mathrm{~m} \mathrm{sec}^{-1}$ and $5{ }^{\circ} \mathrm{C} \mathrm{km}^{-1}$. $\Delta P$ 's increase with the height of the level $\left(z_{c}\right)$ when $z_{c}$ is less than $3 \mathrm{~km}$ and decrease with the height when $z_{c}$ is more than $3 \mathrm{~km}$. When $z_{c}$ is less than $3 \mathrm{~km}$, the trough just bellow the critical level above the leeward foot of the mountain range does not develop sufficiently, and when $z_{c}$ is more than $3 \mathrm{~km}$, the local depressions are intensified at a little upstream point of the foot of the mountain range.

\section{Conclusions}

Unusually deep local depressions are occasionally observed at Urakawa, on the foot of the Hidaka mountain range. The distributions of temperature and wind speed in the representative day (0600 GMT on 27 September 1958) show that there are both an inversion layer and a critical level as shown Fig. 2. Two types of flow are adopted as an initial condition for numerical simulations to investigate the local depression: one is a uniform flow with an inversion layer and the other is a shear flow including a critical level with an uniform vertical gradient of potential temperature. The surface pressure differences $(\Delta P)$ between the both feet of mountain range 
in the shear flow is much larger than those in the uniform flow.

The characteristics of $\Delta P$ of the shear and uniform flows are investigated numerically integrating the basic equations. In the case of the uniform flows, $\Delta P$ 's increase with $U$ for small $U$ region- and maintain almost constan small value for large $U$ region as shown in Fig. 8. $\Delta P$ 's increase with vertical gradient of potential temperature as shown in Fig. 9. In the case of the shear flows with a critical level, $\Delta P$ 's depend largely on $U, \Delta \theta / \Delta z$ and the height of the critical level $z_{c}$. The calculated data are not sufficiently analyzed to these parameters, but as shown in Fig. 8, $\Delta P$ 's increase proportionally with $U$ monotonically, and as shown in Fig. 9, they increase with the increasing rate as five times large as those of the uniform flow.

The flow in which the extraordinary deep local depressions are observed are expected to be likely as shown in Fig. 5. The influences of the mountain range on the atmosphere diminish rapidly above the critical levels. There are large troughs just bellow the original critical levels above the leeward foot of the mountain (the point at $x=15 \mathrm{~km}$ ) as described in Section 3. In the early stages of the time integrations, many small Richardson number regions and many "cat's eyes" appear in the vicinity of the critical levels. In the final stages small Richardson number regions are restricted within narrow area in the windward side of the trough. In the vicinity of the critical levels, Kelvin-Helmholtz billows develop (Tanaka, 1975). The large trough seems to be a kind of such a Kelvin-Helmholtz billow. The local depressions on the foot of the mountain range are intensified by the troughs (or by the reradiation of internal gravity waves from the trough) and would be detected as local deep one at Urakawa. In the case of the uniform flow, the turbulence due to the mountain range is observed in the atmosphere at any level, and the local depressions are intensified on the mid-slope of the mountain range as shown in Fig. 4. These would not be detected as local deep depressions on the foot of the mountain range.

Last, the hydrostatic approximation might be insufficient to represent the flow over a mountain of the scale in this study. However, in the shear flows with a critical level, the motions of the air are almost restricted under the critical levels. In that case, the vertical scales of the motion are very small and the hydrostatic approximation is expected to represent the motions sufficiently.

\section{Acknowledgement}

The author is grateful to Professor Gaishi Onishi of National Defense Academy for his kind suggestions.

\section{References}

Arakawa S. 1960: On the Hidaka-Shimokaze Studies on the Fallwind (Part 1). J. Meteor, Res., 12, 911-919.

Arakawa S. and T. Oobayashi, 1968: On the numerical Experiments by the Method of Characteristics on One-Dimensional Unsteady Airflow over the Mountain Ridge. Pap. Meteor. Geophys., 19, 341-361.

Arakawa S. and M. Okano, 1976: A Numerical Experiment on the Deformation of Cold Frontal Surface due to Mountain Range. J. Meteor. Res., $28,1-10$.

Elliassen E. and E. Palm, 1960: On the Transfer of Energy in Stationary Mountain Waves. Geofysiske Publikasjoner, 22, 1-23.

Fulukawa T., 1937: Numerical Experiments of the Airflow over Mountains 1. Uniform current with constant static stability. J. Meteor. Soc. Japan, 51, 400-419.

—_ 1977 : Numerical Experiments of Airflow over Mountains 2. Some Comparisons of Linear and Nonlinear Treatment of the Equation System and Lower Boundary Condition. J. Meteor. Soc. Japan, 55, 325-340.

Geller M. A., H. Tanaka and D.C. Fritts, 1975 : Production of Turbulence in the Vicinity of Critical Levels for Internal Gravity Waves. $J$. Atmos. Sci., 32, 2125-2135.

Houghton D. D. and A. Kasahara, 1968: Nonlinear Shallow Fluid Flow Over an Isolated Ridge. Comm. on Pure and Appl. Math., 21, 1-23.

Klemp J.B. and D.K. Lilly, 1975: The Dynamics of Wave-Induced Downslope Winds. J. Atmos. Sci., 32, 320-339.

- 1978: Numerical Simulation of Hydrostatic Mountain Waves. J. Atmos. Sci., 35, 78-107.

Long R.R., 1952: Some Aspects of the Flow of Stratified Fluids I. A Theoretical Investigation. Tellus, 5, 42-57.

, 1955: Some Aspects of the Flow of Stratified Fluids III. Continuous Density Gradients. Tellus, 7, 341-357. 
Scorer R.S., 1949: Theory of waves in the lee of mountains. Quart. J. Roy. Meteor. Soc., 75, 41-56.

Scorer R.S. and H. Klieforth, 1958: Theory of mountain waves of large amplitude. Quart. J. Roy. Meteor. Soc., 85, 131-143.

Tanaka H., 1974: Quasi-Linear and Non-Linear In- teractions of Finite Amplitude Perturbations in a Stably Stratified Fluid with Hyperbolic Tangent Shear. J. Meteor. Soc. Japan, 53, 1-31. , 1975: Turbulent Layers Associated with a Critical level in the Planetary Boundary Layer. J. Meteor. Soc. Japan, 53, 425-439.

\title{
日高山脈の風下に現われる局所低圧部に関する，数値計算による研究
}

\author{
遠 峰 菊 郎 \\ 防衛大学校地学教室
}

地表付近において東風成分が卓越する場合, 北海道, 日高山脈の西側の浦河において, 異常に深い局所低圧 部がしばしば観測されることはよく知られている。地表において東風が卓越する場合，日本上空の偏西風との 間に, 通常クリティカルレベルが存在する。本研究は上記の局所低圧部が，このクリティカルレベルによるも のであることを示している。その結果は以下の通りである。

1）一様流の場合, 山脈の雨すその地表気圧の差は, 風速が小さい場合は風速とともに増大し, 風速が大さ 小場合は小さい一定値となる。

2) 局所低圧部は山すそではなく，山脈の中腹に見られ，上層の大気は山脈により多大の影響を受ける。

3）クリティカルレベルを含むシアー流の場合, 地表気圧差は風速とともに増大する。

4）局所低圧部は山すそに現われ，クリティカルレベルより上層の大気は，山脈の影響をあまり受けない。 